\title{
Autoantibodies and genetic factors associated with the development of Type 1 (insulin-dependent) diabetes mellitus in first degree relatives of diabetic patients
}

\author{
C. Thivolet ${ }^{1,4}$, B. Beaufrère ${ }^{3}$, L. Geburher ${ }^{2}$, P. Chatelain ${ }^{3}$, J. Orgiazzi ${ }^{4 *}$ and R. François ${ }^{3 *}$ \\ 1 Clinique Endocrinologique, Hopital de l'Antiquaille, \\ ${ }^{2}$ Laboratoire d'Histocompatibilité, Centre de transfusion sanguine, \\ ${ }^{3}$ Service de Pédiatrie, Hopital Edouard Herriot, \\ ${ }^{4}$ INSERM U 197, Faculté Alexis Carrel, Lyon, France
}

\begin{abstract}
Summary. Factors associated with diabetes onset were analysed for their predictive value in 708 first-degree relatives of Type 1 (insulin-dependent) diabetic patients including 374 parents and 308 siblings of Type 1 diabetic patients. Relatives were prospectively followed for 2304 subject years with blood samples for specific autoantibody evaluation. Islet cell cytoplasmic autoantibody titres were quantified in Juvenile Diabetes Foundation units with a threshold of positivity of 5 units. Insulin autoantibodies were determined using Tyr-A14 iodinated human insulin. HLA typing was performed in $92 \%$ of the relatives. During the time of study, 17 of $646(2.6 \%)$ relatives showed islet cell antibodies. During follow-up, eight relatives developed diabetes, including six with high islet cell antibody titre. Taking titres above 20 units increased the positive predictive value from $35 \%$ to $75 \%$ whereas the presence of insulin autoantibodies did not increase the positive predictive value for the disease. Analysis of metabolic profiles months before the onset of diabetes by either oral or intravenous glucose loads, indicated a considerable level of
\end{abstract}

heterogeneity with relatives with a high islet cell antibody titre who rapidly developed insulin-dependent diabetes, whereas others remained insulin-independent during the same observation period despite comparable titres. This study clearly indicates that initial islet cell antibody titre is not sufficient to predict individual outcome. Follow-up samples are clearly needed to monitor progression of the disease. Few relatives with persistent immunologic positivity progress to clinical Type 1 diabetes, suggesting that non-progressive and sub-clinical Beta-cell dysfunction is common. Despite current knowledge and available genetic and immune markers, early identification of the relatives progressing to clinical diabetes is still difficult and does not allow at the present time aggressive immunointervention at the prediabetic stage.

Key words: Islet cell autoantibodies, Type 1 (insulin-dependent) diabetes mellitus, first degree relatives, prediction.
The presence of autoimmune markers in high risk individuals and newly-diagnosed Type 1 (insulin-dependent) diabetic patients [1] as well as experimental animal models where autoimmune effector $\mathrm{T}$ cells can cause Betacell destruction [2], strongly support the concept that Type 1 diabetes results from an immune mediated phenomenon in genetically susceptible individuals. The morbidity associated with diabetes has encouraged research into ways to cure or prevent this chronic disease. Recent immunointervention trials have indicated that if such treatment is to be effective it should be initiated at the early stages of the disease [3, 4], at a time where the residual Beta-cell mass is sufficient to fulfill insulin needs. Evidence has accumulated that despite its acute onset, Type 1 diabetes is preceded by a long prodromal period

* Members of the Lyons' family study also include Prs F. Berthezène, R. Mornex, J. Tourniaire during which Beta-cells are progressively destroyed. Family studies have shown that the majority of those first-degree relatives who became diabetic had islet cell cytoplasmic autoantibodies (ICA) months before diagnosis [5-8]. However, in order to determine the predictive value of these markers and to analyse the rate of Beta-cell failure, a large number of relatives must be screened for circulating autoantibodies and followed up for long periods. In a previous study [8], we reported that most ICA positive relatives do not progress to developing the disease, indicating that additional factors are required for the progression of Beta-cell destruction. Further identification of those individuals at very high risk for the disease would be of clinical importance in order to decide the risk/benefit ratio of non-specific immunosuppressive treatment prior to weight loss and ketoacidosis. On the other hand, identification of low risk individuals would have also a beneficial psychological impact. In the 


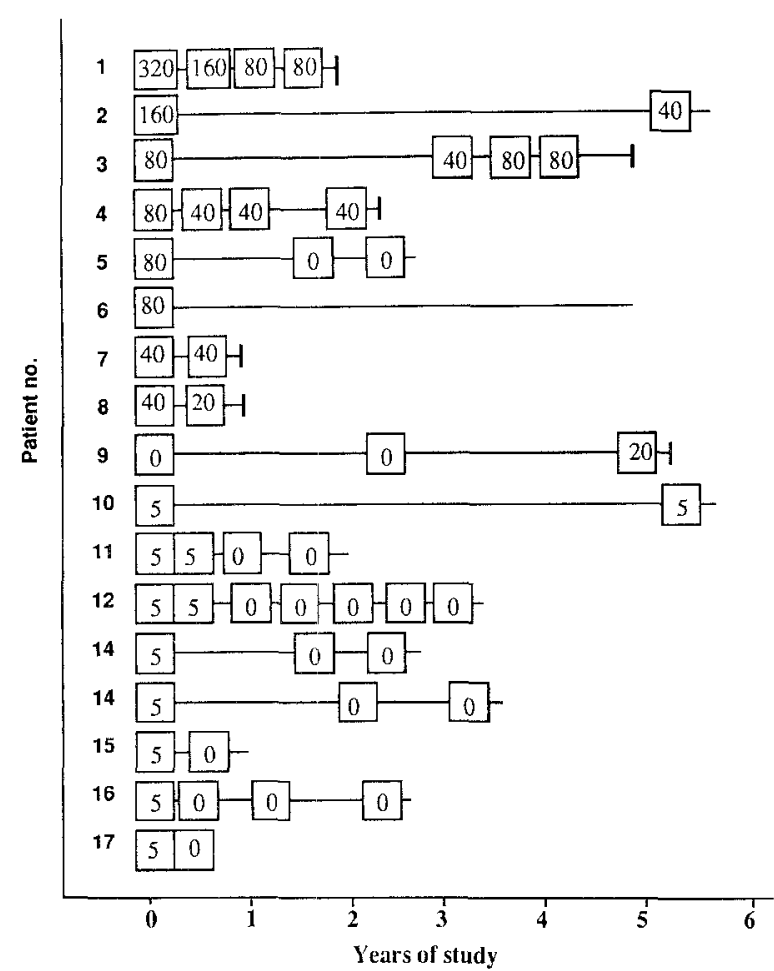

Fig. 1. Evolution of islet cell autoantibody (ICA) titres during follow-up in 17 ICA positive relatives. The bar indicates diabetes onset

present prospective study, we examined the influence of genetic and immunological parameters on the metabolic outcome of first degree relatives of Type 1 diabetic patients and determined the predictive value of these markers for the onset of the disease.

\section{Subjects and methods}

All first-degree relatives were enrolled after informed consent in a screening programme for Type 1 diabetes from 1982. The characteristics of this family study referred to as the Lyons' family study have been previously published [8]. Between January 1982 and October 1990, 708 first-degree relatives were enrolled in the screening programme, including 374 parents, 308 siblings, and 26 children of 228 Type 1 diabetic patients. The mean number of relatives per family tested was 3.1 [1-7]. This population was composed from 6 multiplex families. Genetic determination was performed in $658(93 \%)$ relatives and $220(96 \%)$ patients. Determination of circulating autoantibodies was done at least once in $646(91 \%)$ individuals upon entry into the study and at least twice in 344 of them. Relatives had $1.6 \pm 0.9$ blood samples and the total follow-up represented 2304 person-years with a mean observation period of 3.6 years.

\section{Islet cell cytoplasmic and insulin autoantibodies}

Four micron sections of frozen pancreas from a human cadaver of blood group 0 were used as substrates for the indirect immunofluorescence assay, using a sheep anti-human IgG FITC conjugate (Wellcome Laboratories, Beckenham Kent, UK) diluted 1:50. The end point titres causing detectable fluorescence were converted in Juvenile Diabetes Foundation (JDF) units using a standard curve raised between end point titres of multiple dilutions of an international reference serum [9]. Our laboratory participated in ICA proficiency tests and in the last JDF sponsored international diabetes workshop. During the last two years, our average results were $90 \%$ for validity, $95 \%$ for consistency, $95 \%$ for specificity and $80 \%$ for sensitivity.

Insulin autoantibodies were determined by a competitive fluidphase radiobinding assay as previously documented [8] by a modification of the radioassay procedure initially described by Palmer et al. [10] according to international workshop recommendations [11]. Briefly, sera were stripped of insulin with charcoal-Dextran prior to incubation for 5 days at $4^{\circ} \mathrm{C}$ with $7500 \mathrm{ng} / \mathrm{ml}$ of Tyr-A14 monoiodinated insulin (specific activity $270 \mu \mathrm{Ci} / \mu \mathrm{g}$ IRI, NovoBiolabs, Bagsvaerd, Denmark). Immune complexes were separated using cold polyethylene glycol. A competitive displacement with $4000 \mathrm{ng} / \mathrm{ml}$ of serum of unlabelled human insulin (Lilly, Indianapolis Ind., USA) was performed systematically for each sample to assess specific antiinsulin binding. The mean value $+3 \mathrm{SD}$ of 86 normal sera was $1.3 \%$.

\section{Genetic studies}

HLA class I and class II alleles were determined by serological methods using reference sera. The distribution of DR alleles in our diabetic population and a control panel of normal individuals has been published [8]. The distribution of high risk haplotypes such as DR3-DQw2 and DR4-DQw8 as well as that of the low risk haplotypes DRw15-DQw6 and DR4-DQw7, was studied in both relatives and probands. In a limited number of cases unsolved by serological HLA DQ typing, DQ-B chain sequence polymorphism at position 57 was also analysed after DNA amplification by the polymerase chain reaction and dot-blot analysis with specific ${ }^{32} \mathrm{P}$-radiolabelled probes [12].

\section{Metabolic studies}

The metabolic status of ICA positive relatives was determined after an oral charge of $75 \mathrm{~g}$ of glucose (OGTT). Diagnosis of glucose intolerance and diabetes was based on the National Diabetes Data Group recommendations [13]. Insulin secretory reserve was estimated after $12 \mathrm{~h}$ fast in subjects on a diet that included at least $250 \mathrm{~g}$ carbohydrate. The intravenous glucose tolerance test (IVGTT) was performed by an intravenous infusion of $0.5 \mathrm{~g} / \mathrm{kg}$ of glucose administered over $2 \mathrm{~min}$. Blood samples were obtained at 1, 3 and $60 \mathrm{~min}$ after glucose injection. The first percentile for the sum of $1 \mathrm{~min}+3 \mathrm{~min}$ insulin of the response in 83 control subjects (mean age 22.9 years, range $7-31$ years and mean BMI 21.5 , range 19-33) was $50 \mathrm{mU} / \mathrm{l}$. Intra-individual variation was $49 \%$, and inter-subject variation calculated in 18 control subjects was $21 \%$. Oral glucose tolerance test (OGTT) was performed after an oral charge of $75 \mathrm{~g}$ or $1.5 \mathrm{~g} / \mathrm{m}^{2}$ of glucose depending on the age of the subjects.

\section{Statistical analysis}

Relative risks were calculated using the appropriate formulae. Statistical comparisons between entry and the latest follow-up were made using paired $t$-test. Comparison of ICA titre between groups of relatives was performed using the Mann-Whitney U-test. Results are expressed as mean $\pm \mathrm{SD}$.

\section{Results}

\section{Autoantibody determination}

The frequency of ICA levels above the limit of detection (5 JDF units) was $2.6 \%$ (17 of the 646). For each ICA positive relative, clinical information, HLA status and length 


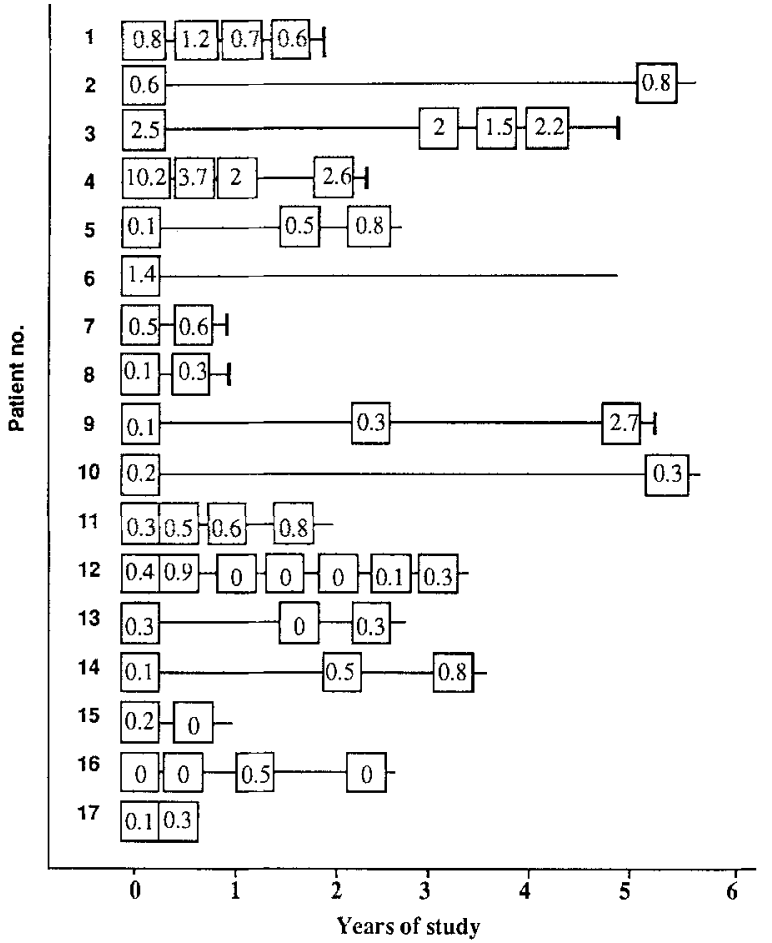

Fig. 2. Evolution of insulin autoantibody (IAA) levels during follow-up in 17 ICA positive relatives. The bar indicates diabetes onset. A specific binding over $1.3 \%$ was considered as positive

of discordance with their diabetic proband are presented in Table 1. Ages ranged from 10 to 48 years (mean age 25.1 years) and length of discordance from 2 to 40 years (mean duration 15.3 years). Among the 17 ICA positive relatives, eight remained consistently ICA positive on follow-up, one could be tested only once and seven became ICA negative. One relative became positive during followup. Among ICA positive first degree-relatives, a significant difference in titre was found between those who became diabetic during follow-up $(n=5)$, and others who remained unaffected (mean titre $\pm \mathrm{SD}: 112 \pm 52$ vs $23.5 \pm 15$, $n=7, p<0.01$ ). ICA titres were above $20 \mathrm{JDF}$ units in all those relatives in whom diabetes developed and with one exception, peak antibody levels were found at entry. As indicated in Figure 1, seven of the eight patients with ICA above $40 \mathrm{JDF}$ units remained subsequently positive including five in whom diabetes occurred. All relatives with low ICA titres at first analysis, became negative in followup samples and none developed diabetes. During the study, two of the $629(0.3 \%)$ ICA negative relatives became diabetic. However, in one subject the length of serum sampling period was too short to exclude any ICA positivity months or years before clinical onset. Altogether, the positive predictive value of ICA increased from $35 \%$ to $75 \%$ when high titre was taken into account.

Insulin autoantibodies (IAA) were determined at least once in 621 relatives. Specific binding values exceeded the upper limit of normal values in 14 relatives $(2.2 \%)$ (Table 2). Four ICA positive relatives had also IAA and three ICA-IAA positive relatives became diabetic during follow-up (Fig. 2). Insulin binding activities found initially in two other relatives before diabetes onset [8], were not confirmed with the competitive IAA test using cold insulin. Among IAA positive relatives the three ICA positive individuals who developed Type 1 diabetes had higher IAA values $(p<0.001)$. The two ICA negative relatives who subsequently became diabetic did not have IAA. No significant correlation was found between IAA levels and time from onset of diabetes.

\section{Genetic analysis}

The distribution of class II alleles was analysed in 658 relatives and compared to that of 220 probands and 192 control subjects. As indicated in Table 3, the repartition of class II alleles and DR-DQ haplotypes in relatives reflected the specific distribution found in the diabetic group. In comparison to control subjects, our panel of first degree relatives showed a two-fold increase in the frequency of DR3 and DR4 alleles as well as a ten-fold increase of DR3/DR4 heterozygotes. The majority, but not all, DR3 DR4 alleles found in relatives were also shared
Table 1. Clinical and genetic information on 17 first degree relatives with islet cell autoantibodies (ICA). Relative number 9 was found to be ICA positive after 5 years of follow-up, 3 months before diabetes onset

\begin{tabular}{llllllr}
\hline Subject & $\begin{array}{l}\text { Age } \\
\text { (years) }\end{array}$ & Sex & $\begin{array}{l}\text { ICA titre } \\
\text { (JDF units) }\end{array}$ & Relation to proband & $\begin{array}{l}\text { DR-DQ- } \\
\text { haplotypes }\end{array}$ & $\begin{array}{l}\text { Discordance } \\
\text { (years) }\end{array}$ \\
\hline 1 & 43 & F & 320 & Parent & $3-2 / 4-8$ & 34 \\
2 & 17 & F & 160 & Haploidentical sibling & $13-6 / 3-2$ & 3 \\
3 & 15 & M & 80 & Haploidentical sibling & $4-8 / 13-6$ & 16 \\
4 & 18 & M & 80 & Haploidentical sibling & $13-6 / 3-2$ & 4 \\
5 & 10 & F & 80 & Haploidentical sibling & $12-7 / 4-3$ & 8 \\
6 & 13 & M & 80 & Identical sibling & $4-8 / 4-3$ & 4 \\
7 & 21 & M & 40 & Identical sibling & $2-1 / 4-3$ & 6 \\
8 & 18 & F & 40 & Haploidentical sibling & $4-3 / 2-N D$ & 4 \\
9 & 11 & M & 20 & Identical sibling & $3-2 / 3-2$ & 2 \\
10 & 43 & M & 5 & Parent & $2-1 / 4-3$ & 35 \\
11 & 11 & M & 5 & Child & $4-8 / 1-5$ & 8 \\
12 & 38 & F & 5 & Parent & $3-2 / 11-7$ & 33 \\
13 & 39 & F & 5 & Parent & $3-2 / 4-3$ & 3 \\
14 & 39 & F & 5 & Parent & ND & 30 \\
15 & 32 & F & 5 & Parent & $13-6 / 16-5$ & 27 \\
16 & 48 & M & 5 & Parent & $4-3 / 11-7$ & 40 \\
17 & 11 & M & 5 & Identical sibling & $4-3 / 3-2$ & 3 \\
\hline
\end{tabular}

JDF = Juvenile Diabetes Foundation; ICA = islet cell autoantibody 


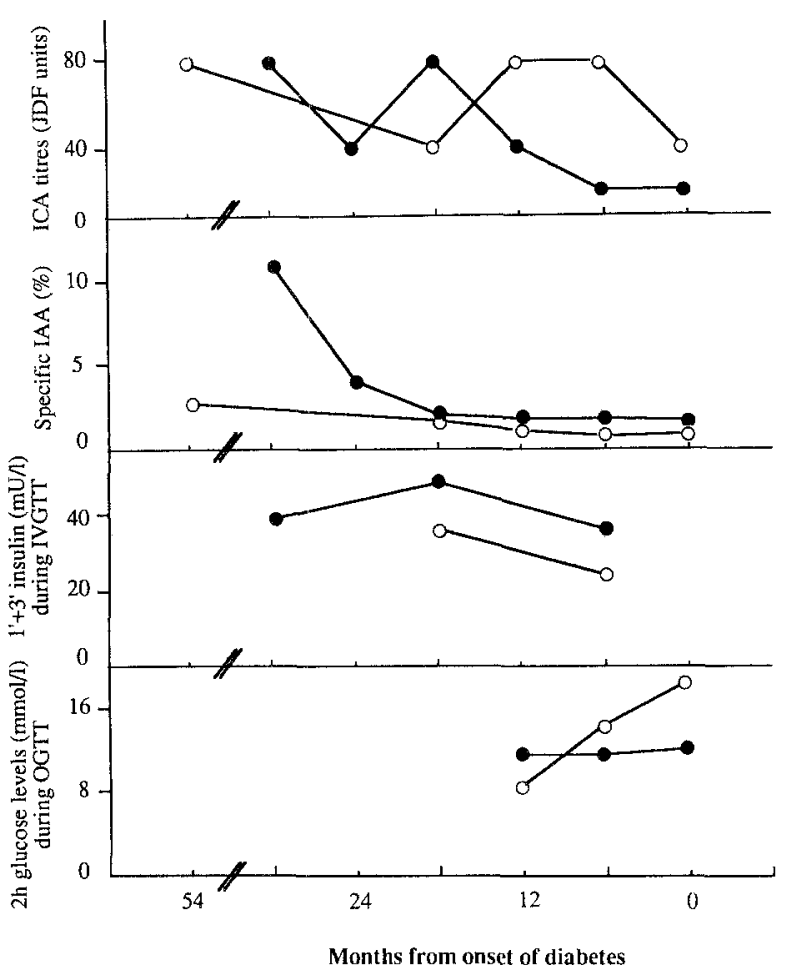

Fig.3. Evolution of islet cell autoantibody (ICA) titres, insulin autoantibody (IAA) levels, 1st phase insulin response to intravenous glucose tolerance test (IVGTT, and $2 \mathrm{~h}$ blood glucose levels during oral glucose tolerance test (OGTT) in two relatives who became diabetic during the study

with probands. The frequency of high-risk haplotypes such as DR3-DQw2 or DR4-DQw8 shared between relatives and probands was higher than low-risk haplotypes. The six ICA positive and the two ICA negative relatives who developed diabetes during the study had at least one haplotype in common with their diabetic proband but shared haplotypes varied from one individual to another. However, all these relatives had either DR3-DQw2 or DR4-DQw8 haplotypes with 57-Asp negative DQ-B chains. No particular class II allelic combination was associated with a more rapid metabolic deterioration.

Presence of ICA or IAA occurred in different genetic combinations. However, the presence of ICA was linked to the presence of 57-Asp negative DQ-B chain at a single or double dose, closely reflecting the genetic background of their diabetic probands. However, the high level of susceptibility due to the presence of high titre ICA was not associated with a specific HLA pattern.

\section{Metabolic outcome of ICA positive relatives}

Six out of the eight relatives who developed diabetes underwent an OGTT and/or IVGTT during the prediabetic period. Four individuals had a documented IVGTT below the 1st percentile at the initial test, between 3 and 36 months before the onset of diabetes. No correlation was found between IVGTT values and time from clinical onset. Little variability was found in these subjects with no conversion to normal insulin response to glucose. Fasting blood glucose levels remained within the normal range a few months before onset, although a progressive rise was noticed. Immunologic and genetic parameters could not differentiate relatives with rapid from those with slow and progressive deterioration of Beta-cell function. Figure 3 illustrates the differences in metabolic profiles in two relatives with high titre ICA. While one developed ketoacidosis and insulin deficiency, the other had normal fasting blood glucose levels but remained insulinindependent at the most recent follow-up despite pathological first phase insulin responses and abnormal OGTTs. Both had high risk DQ alleles, ICA at $80 \mathrm{JDF}$ units at entry in the study and IAA in the same range.

\section{Discussion}

This study further supports the presence of islet cell and insulin autoantibodies months or years before development of clinical diabetes. Large scale prospective studies
Table 2. Characteristics of 14 insulin autoantibody (IAA) positive relatives. DRX indicates non DR3-non DR4 alleles

\begin{tabular}{llllrll}
\hline & Relation to proband & $\begin{array}{l}\text { Age } \\
\text { (years) }\end{array}$ & $\begin{array}{l}\text { ICA titre } \\
\text { (JDF units) }\end{array}$ & Peak IAA & DR & Follow-up \\
\hline ICA+ & & & & & & \\
Brother & Haploidentical & 15 & 80 & 2.5 & DR4/X & Diabetic \\
Brother & Haploidentical & 18 & 80 & 10.2 & DR3/X & Diabetic \\
Brother & Identical & 11 & 20 & 2.5 & DR3/3 & Diabetic \\
Brother & Identical & 13 & 80 & 1.4 & DR4/4 & Normal \\
Mean & & 14.2 & & 4.1 & & \\
ICA- & & & & & & \\
Brother & Identical & 21 & & 1.3 & DR3/X & Normal \\
Sister & Haploidentical & 18 & & 1.6 & DR3/4 & Normal \\
Mother & Haploidentical & 54 & & 1.3 & DR3/X & Normal \\
Mother & Haploidentical & 40 & & 1.3 & DR3/3 & Normal \\
Sister & Haploidentical & 23 & & 1.3 & DR3/4 & Normal \\
Brother & Identical & 20 & & 1.4 & ND & Normal \\
Brother & Identical & 11 & & 1.6 & DR4/X & Normal \\
Brother & Haploidentical & 23 & & 1.4 & DR3/X & Normal \\
Brother & Haploidentical & 26 & & 1.4 & DR4/X & Normal \\
Brother & Haploidentical & 13 & & 1.3 & DR4/X & Normal \\
Mean & & 25.3 & & 1.4 & & \\
\hline JDF Juven & & & & & \\
\hline
\end{tabular}

$\mathrm{JDF}=$ Juvenile Diabetes Foundation; ICA $=$ islet cell antibody 
Tahle 3. Distribution of high risk class II alleles in first degree relatives and their diabetic probands

\begin{tabular}{|c|c|c|c|c|c|}
\hline & Relatives & Probands & $\begin{array}{l}\text { Control } \\
\text { subjects }\end{array}$ & RR & FE \\
\hline Subjects & $n=658$ & $n=220$ & $n=192$ & & \\
\hline DR3 & $288(43.7 \%)$ & $119(58 \%)$ & $37(19 \%)$ & 6 & 0.49 \\
\hline DR4 & $284(43.2 \%)$ & $136(66 \%)$ & $41(21 \%)$ & 7.1 & 0.57 \\
\hline DR3/4 & $64 \quad(9.7 \%)$ & $69(33.5 \%)$ & $3 \quad(2 \%)$ & 32 & 0.3 \\
\hline \multicolumn{6}{|l|}{ Haplotypes } \\
\hline DR3-DQw2 & $\begin{array}{l}179 / 183^{a} \\
(98 \%)\end{array}$ & $\begin{array}{l}140 / 141 \\
(99 \%)\end{array}$ & & & \\
\hline DR4-DQw8 & $\begin{array}{l}209 / 263 \\
(79.5 \%)\end{array}$ & $\begin{array}{l}130 / 146 \\
(89 \%)\end{array}$ & & & \\
\hline DR4-DQw7 & $\begin{array}{l}54 / 263 \\
(20.5 \%)\end{array}$ & $\begin{array}{l}16 / 146 \\
(11 \%)\end{array}$ & & & \\
\hline
\end{tabular}

a Ratio of specific DR-DQ haplotypes over DR3 or DR4 containing haplotypes - including DR3 or DR4 heterozygotes - in which the DQ-associated allele was characterised

of high risk groups of individuals have established the existence of an asymptomatic phase preceding clinical onset of the disease during which autoimmune markers are present $[5,8,14]$. The fact that the majority of ICA were detected in relatives at entry to the study adds further support to the view that progression to hyperglycaemia may be slow. Indeed, follow-up of ICA negative subjects identified only one identical sibling who became ICA positive shortly before diabetes onset. This result has some importance for the strategy of the screening programmes and should encourage ways of increasing the number of participants rather than developing the followup of ICA negative individuals which should be maintained in those with the highest genetic risk.

Although animal models have clearly indicated that diabetes is a $\mathrm{T}$ cell mediated autoimmune disease [2], presence of ICA remains the best indicator of an ongoing autoimmune process. One of the questions this study was designed to answer, was whether later development of Beta-cell failure could be predicted in ICA positive first degree relatives of diabetic probands. This question remains unanswered due to the occurrence of fluctuating autoantibody levels as well as long periods of ICA positivity without clinical symptoms as previously reported [17]. Variation in substrate sensitivity warrants the conversion of ICA titres into JDF units which increases significantly the positive predictive value. High titre ICA as well as CFICA are closely associated with a higher risk of becoming diabetic. All our ICA positive relatives who became diabetic had ICA above 20 JDF units. As previously documented by Bonifacio et al. [16], quantification of ICA in follow-up samples is therefore clearly needed to accurately predict onset of Type 1 diabetes. However, the results presented here suggest a higher level of heterogeneity. Some individuals with high ICA titres at entry did not develop diabetes within 5 years of follow-up. Others with fluctuating ICA titres became ICA negative during follow-up. In this study, relatives with constant ICA titres above $40 \mathrm{JDF}$ units had a rapid progression to disease. In contrast to previous studies [18,24], presence of IAA did not increase in our study the predictive value since only three out of six ICA positive relatives also had IAA prior to diabetes onset and since none of the ICA negative IAA positive individuals developed the disease. In contrast to what could be observed with ICA, we have not found conversion of IAA values over time which suggests that these two autoantibodies are independent and reflect different pathogenic mechanisms. This study also reports on two ICA-IAA negative relatives with high risk haplotypes who became diabetic during follow-up. Impairment of Beta-cell function and peripheral insulin sensitivity has been described in HLA identical siblings of Type 1 diabetic patients [19]. The genetic background may therefore contribute to subclinical Beta-cell dysfunction which may progress in limited cases to clinical diabetes under the influence of immune and environmental factors. Recent molecular findings bring further insights into the genetic susceptibility to Type 1 diabetes [20-22]. However, a large number of healthy relatives have the susceptible genes. Additional genetic information therefore needs to be incorporated into a full model of genetic susceptibility, including characterization of both DQ-A and DQ-B chains [22]. In the present study, HLA identity did not expose relatives to an increased prevalence of autoantibodies and metabolic alterations. This is in accordance with the fact that HLA associated genes are thought to contribute less than $50 \%$ to the liability.

Alteration of the first phase insulin release during IVGTT has been reported to predict the onset of overt diabetes in pre-diabetic patients within 1.5 years [24]. An important point to be considered is the reproducibility of the measures of Beta-cell function. Some low insulin responders to glucose remained normal after 5 years of follow-up. A decrease in the insulin response to glucose has been reported by Lindgren et al. [25] after puberty. The observation of several relatives who did not progress to insulin-dependency despite low $1 \mathrm{~min}+3 \mathrm{~min}$ insulin values, demonstrates the difficulty in predicting on a single test the metabolic profile and delay from diabetes onset. In addition, normal fasting glucose does not eliminate imminent development of overt disease [26]. The present study and others [27-29], do not support a model of linear loss of Beta-cell mass. The preservation of an insulin reserve sufficient to maintain glucose homeostasis raises the possibility of fluctuation in the activity of immune-mediated destruction of the Beta cells. Factors which in some individuals precipitate rapid deterioration of glucose homeostatic function are not known.

Immunosuppression had been found to be efficient in Type 1 diabetes when given at clinical presentation leading to an increase in the prevalence of complete remissions [3]. However, in order to prevent the disease, such treatment should be given earlier, at a time when the residual Beta-cell mass is sufficient to fulfill insulin needs. The demonstration in ICA positive relatives of a highly variable metabolic outcome emphasizes the difficulties encountered in establishing the value of any preventive treatment given in randomized controlled trials.

Acknowledgements. We thank Dr. D.Penet for establishing normal values for IVGTT and Ms. A. Durand for excellent technical assistance. Members of the Lyons' family study also include Prs F. Berthezène, R. François, R. Mornex, J. Tourniaire. This work was sup- 
ported by the Institut de la Recherche Médicale (Réseau Clinique $\mathrm{n}^{\circ} 488015$ ), by the Scientific Concil of Region Rhône-Alpes and Novo-Nordisk Laboratories.

\section{References}

1. Eisenbarth GS (1986) Insulin-dependent diabetes mellitus: a chronic autoimmune disease. N Engl J Med 314: 1360-1368

2. Makino S, Kunimoto K, Muraoka Y, Mizushima Y, Katagiri K, Tochino Y (1980) Breeding of a non-obese, diabetic strain of mice. Exp Anim 29: 1-8

3. Feutren G, Papoz L, Assan R, Vialettes B, Karsenty G, Vexiau P, Rostu H du, Rodier M, Sirmai J, Lallemand A, Bach JF (1986) Cyclosporin increases the rate and length of remissions in insulin-dependent diabetes of recent onset: results of multicenter double blind trial. Lancet II: 119-124

4. Bougneres PF, Carel JC, Castano L et al. (1988) Factors associated with early remission of Type 1 diabetes in children treated with cyclosporine. N Engl J Med 318: 663-670

5. Barnett AH, Eff C, Leslie RDG, Pyke DA (1981) Diabetes in identical twins, a study of 200 pairs. Diabetologia 20: $87-93$

6. Srikanta S, Ganda OP, Rabizadeh A, Soeldner JS, Eisenbarth GS (1985) First degree relatives of patients with Type 1 diabetes mellitus: islet cell antibodies and abnormal insulin secretion. $\mathrm{N}$ Engl J Med 313: 461-464

7. Tarn AC, Thomas JM, Dean BM, Ingram D, Schwartz G, Bottazzo GF, Gale EAM (1988) Predicting insulin dependent diabetes. Lancet I: $845-850$

8. Thivolet C, Beaufrère B, Betuel H, Geburher L, Chatelain P, Durand A, Tourniaire J, François R (1988) Islet cell and insulin autoantibodies in individuals at high risk of development of Type 1 (insulin-dependent) diabetes mellitus: The Lyon family study. Diabetologia 31: 741-746

9. Boitard C, Bonifacio E, Bottazzo GF, Gleichmann H, Molenaar $\mathrm{J}$ (1988) Immunology and diabetes workshop: report on the third international (stage 3) workshop on the standardisation of islet cell antibodies. Diabetologia 31: $451-452$

10. Palmer JF, Asplin CM, Clemens P, Lyen K, Tatpatti O, Raghu PK, Paquette TL (1983) Insulin antibodies in insulin dependent diabetes before insulin treatment, Science 222: 1337-1339

11. Palmer JP, Wilkin TJ, Kurtz AB, Bonifacio E (1990) The third international workshop on the standardisation of insulin autoantibody measurement. Diabetologia 33:60-61

12. Saiki RK, Walsh PS, Levenson CH, Erlich HA (1989) Genetic analysis of amplified DNA with immobilized sequence specific oligonucleotide probes. Proc Natl Acad Sci USA 86: 6230-6234

13. National Diabetes Data Group (1979) Classification and diagnosis of diabetes mellitus and other categories of glucose intolerance. Diabetes 28: 1039-1057

14. Bruining GJ, Molenaar JL, Grobbee DE, Hofman A, Scheffer GJ, Bruining HA, Bruyn AM de, Valkenburg HA (1989) Ten years follow-up study of islet cell antibodies and childhood diabetes mellitus. Lancet I: 1100-1103

15. Bottazzo GF, Gorsuch AN, Dean BM, Cudworth AG, Doniach D (1980) Complement fixing islet cell antibodies in Type 1 diabetes: possible monitors of active beta cell damage. Lancet I: 668-672

16. Bonifacio E, Bingley PJ, Shattock M, Dean BM, Dunger D, Gale EAM, Bottazzo GF (1990) Quantification of islet cell antibodies and prediction of insulin dependent diabetes. Lancet I: 147-149
17. Spencer KM, Tarn A, Dean BM, Lister J, Bottazzo GF (1984) Fluctuating islet cell autoimmunity in unaffected relatives of patients with insulin dependent diabetes. Lancet I 764-766

18. Dean BM, Becker F, McNally JM, Tarn AC, Schwartz G, Gale EAM, Bottazzo GF (1986) Insulin autoantibodies in the prediabetic period: correlation with islet cell antibodies and development of diabetes. Diabetologia 29: 339-342

19. Johnston C, Raghu P, McCulloch DK, Beard JC, Ward WK, Klaff LJ, McKnight B, Bergman RN, Palmer JP (1987) $\beta$-cell function and insulin sensitivity in non diabetic HLA-identical siblings of insulin-dependent diabetics. Diabetes 36: 829-837

20. Todd JA, Bell JI, McDewitt $H$ (1987) HLA DQß gene contributes to susceptibility and resistance to insulin dependent diabetes mellitus. Nature 329: 599-604

21. Todd JA (1990) Genetic control of autoimmunity in Type 1 diabetes. Immunol Today 11: 122-129

22. Khalil I, d'Auriol L, Gobet M et al. (1990) A combination of HLA DQ- $\beta$ Asp57 negative and HLA DQ- $\alpha$ Arg52 confers susceptibility to insulin dependent diabetes mellitus. J Clin Invest 85: 1315-1319

23. Johnston C, Millward BA, Hoskins P, Leslie RDG, Bottazzo GF, Pyke DA (1989) Islet cell antibodies as predictors of the later development of Type 1 (insulin-dependent) diabetes. Diabetologia 32: $382-386$

24. Srikanta S, Ricker AT, McCulloch DK, Soeldner JS, Eisenbarth GS, Palmer JP (1986) Autoimmunity to insulin, beta cell dysfunction and development of insulin dependent diabetes mellitus. Diabetes 35: 139-142

25. Lindgren F, Dahlquist G, Efendic S, Moller E, Persson B, Thalme B, Landin Olsson M (1987) Glucose insulin response and insulin sensitivity is not related to HLA type but to age in young siblings of Type 1 (insulin-dependent) diabetic patients. Diabetologia 30: 727-732

26. Bleich D, Jackson RA, Soeldner JS, Eisenbarth GS (1990) Analysis of metabolic progression to Type 1 diabetes in ICA + relatives of patients with Type 1 diabetes. Diabetes Care 13: 111-118

27. Thivolet C, Betuel H, Orgiazzi J et al. (1989) HLA DR-DQ haplotypes as well as islet cell autoantibodies do not predict the rate of Beta-cell loss in first degree relatives of Type 1 diabetic patients. Diabetologia 32: 547 (Abstract)

28. Heaton DA, Millward BA, Gray IP, Tun Y, Hales CN, Leslie RDG (1987) Evidence of B cell dysfunction which does not load on to diabetes: a study of identical twins of insulin dependent diabetes. Br Med J 294: 145-146

29. McCulloch DK, Klaff LJ, Kahn SE et al. (1990) Nonprogression of subclinical $\beta$-cell dysfunction among first-degree relatives of IDDM patients. Diabetes 39:549-556

Received: 30 July 1990

and in revised form: 13 November 1990

Dr. C. Thivolet

Clinique Endocrinologique

Hopital de l'Antiquaille

1 rue de l'Antiquaille

F-69321 Lyon Cedex 05

France 